\title{
Swart Teologie
}

\author{
HG v d WESTHUIZEN
}

\section{Inleiding}

Vir sover Swart Teologie uit die agtergrond van die genitiefsteologieë ontspring, het dit sy instigasie en oorsprong nie by Swartmense as sodanig nie, maar by die "rooi dier" -mense van die teologie van die apostasie - die valse kerk (Openb 17:3). "Die wortels daarvan lê nie soseer in Amerika of in die tradisie van Afrika nie maar veel eerder in die moderne Teologie van die Rewolusie wat sedert die verandering van die Wêreldraad van Kerke te Genéve (1966) soveel opgang maak" (1:95).

Ons moet inderdaad as Christene altyd met die gees van nederigheid (1:97), dit wil sê in ooreenstemming met die totale Bybelse lig, sake beoordeel. So ook die Swart Teologie. Dat daar in welke saak, selfs in die woorde van Satan self, positiewe elemente of woorde van God kan wees, is ' $n$ feit. Selfs die Satan het Bybelwoorde aangehaal in die versoekings van Jesus en hy het na God se woorde verwys by die versoeking van Adam en Eva. Maar geen saak of pleitrede of stelling kan beoordeel word net op onderdele nie. Die beslissende vraag is in welke perspektief die geheel geplaas is en in welke verband die geheel tot God staan, soos geopenbaar in sy Woord. Dat daar in die Swart Teologie, wat dit ookal mag wees, ligarms of Bybelse of positiewe elemente in sal wees, kan ons byvoorbaat aanvaar. Vir sover daar elemente van die Afrikase Teologie in die Swart Teologie, is, is hierdie elemente in ' $n$ Bybelse perspektief goed. Met ' $n$ Teologie van Afrika kan 'n tipering aangedui word en nie juis 'n genitiefsteologie nie. So 'n Afrikase Teologie verskil dan in onderdele van ' $n$ moontlike Europese Teologie, 'n Amerikaanse Teologie, 'n Asiatiese Teologie ensovoorts. Maar as Bybelse en Christelike Teologieë moet hulle in uitgangspunte en hoofsake ooreenkom. Waar "African Tradional Religion" heidens is en "Black Theology" - soos ons sal sien - swart ekumenistiese sinkretisme is, kan "African theology" 'n term wees om die Bybelse teologie te beoefen deur Afrika-mense. Aan die ander kant word egter ook gesê: "it is wrong to suggest that there is a fundamental difference between what is now called Avrican Christian Theology and black theology. The latter is one expression of the former" (2:156). Daarom, moet gewaak en gewerk word anders sal ' $n$ term of naam alleen nie 'n teologie suiwer hou nie. So is African Theology net soos black Theology nie vanselfsprekend suiwer Bybels nie. "The two systems 
also give little or no significance to the Biblical fact of individual salvation. A universalistic view of redemption is at least implied in both systems. But it must be stressed that Black Theology is not identical with African Theology" $(3 ; 49)$.

Die nederige gesindheid waarmee ons ook die Swart Teologie, moet benader, moet ook voortspruit uit die leer van die uitverkiesing en die volharding van die heiliges (Dordtse Leerreëls). Ook moet 'n potensiële Wit Teologie so benader word. Wanneer wit kapitalisme of wit onderdrukking of wit-watter-sonde-ookal as onveranderbare wil van God gepropageer word, kan dit sekerlik Wit Teologie genoem word. Maar die een "teologie" moet nie die ander "teologie" benader asof 'n teologie of die persone wat daardie teologie bedryf die Christus of Middelaar is nie. Christus alleen (Hand 4:12;1 Tim 2:5) verlos ons en behou ons deur sy Woord en Gees. "Vind ons nie hierin die ou verkiesingsleer, die antwoord op die moderne vraag van die bekeerde heiden (= swart Christen, Swart Teologie H G van der Westhuizen) wat elke dag sien en hoor oor radio en pers hoedat die 'ou' Christene val en struikel, hoedat by die sendende kerk al te dikwels leer en lewe mekaar nie dek nie? Sal hulle ons in ons swakheid en die heerlikheid van God in sy oneindige genade nie beter verstaan as ons hierdie kosbare erfenis, soos bely uit die Woord van God, duidelik en helder en volledig aan hulle verkondig nie?" (4:96).

Die sendingbeleid (5) van die Nederduitsch Hervormde Kerk van Afrika toon baie duidelik aan dat die swartmense of watter nasionaliteit ookal, nie eers imperialisties of kolonialisties van sy nasionale ontman moet word om sy siel te red en van hom 'n Christen te maak nie. 'n Mens se lewe, jou ouers, jou land en volk, taal en kultuur, is Godgegewe gawes. Dit moet ons waardeer en behou en ook toelaat dat 'n ander syne kan waardeer en behou. Maar omdat ons in sonde geval het, is ' $n$ mens se lewe van nature sondig en so ook alles wat daarmee saamgaan soos jou kultuur en religieuse tradisies. Daarom moet jou hart tot Christus bekeer word wat alleen kan geskied deur 'n radikale eksterne inwerking op jou deur die Woord en Gees van God. Die verlossende Woord van God word inheems, mens soos ons is, maar bly sonder sonde en bly dus Seun van God. Daarom moet ons unieke Christelike geloof wat wel die natuurlike en tradisionele en nasionale vorme kan aanneem, wesenlik uniek bly. Christus het mens geword maar God gebly. So moet die Christelike geloof ook Europees, Afrikaans, Japanees ensovoorts word, maar Christelike geloof bly. Die gestalte wat aangeneem word, moet nie maar net geïnkorporeer word deur die Chrtistelike geloof nie, maar bekeer word. Die Christelike godsdiens moet inderdaad nie 'n Europese potplant in Afrika wees nie. Die Christelike godsdiens van Afrika moet in Afrika se bodem self groei. Maar Jesus wat in die mensheid 
kom groei het, het van buite, van bo, van God gekom. Hy het uniek gebly en die aarde waarin Hy kom groei het (sy mensheid), verander - sondeloos gemaak. Die Christelike geloof word inderdaad van buite in Europa, Afrika, ensovoorts geplant. Die Christelike geloof sal dus immer in elke Christelike godsdiens, en so ook in die Afrika se Christendom, uniek wees.

Ander begrippe wat in hierdie verband gebruik word, is:

Inheemswording: Dit is meer 'n begrip wat vanuit die sendende kerk gesien "die verwesenliking (is) van die drie 'selves': selfonderhoud, selfregering en selfuitbreiding ..." (6:17).

Afrikanisasie: Die aksent hier "dui op 'n dringende program van aksie ... wanneer dit die Afrikaan is wat oor sy eie sake praat ..." (6:16; vergelyk ook 9:29).

'n Belangrike vraag is hoe afrikanisasie en Swart Teologie met mekaar in verband staan (6:25)? By fynere ontleding blyk dit dat vanweë byvoorbeeld "die kompleksiteit van die Swart Teologie (en die Afrikanisasie $-H$ G van der Westhuizen) as verskynsel ... dat ' $n$ indelingsprinsipe ten opsigte van die verskillende verskynsels moeilik gevind kan word" (6:31). Terwyl afrikanisasie, gesien sy verstaanbare reaksionêre oorsprong (6:5-8), ook negatiewe en kritiseerbare komponente en tendense kan bevat, kom dit egter nader na wat die Nederduitsch Hervormde Kerk van Afrika in sy sendingbeleid bedoel met volkskerke. Afrikanisasie en Afrikase Teologie dra sekerlik meer 'n etnologiese lading terwyl Swart Teologie meer 'n antropologiese en sosiologiese lading dra (6:26). Indien die etnologiese by die afrikanisering nie die inhoud van die teologie bepaal nie, maar die konteks, kan ons afrikanisering teologies beskryf as "swart" Teologie. Dan gaan dit "hoogstens om die benne esse van die kerk" (6:34). Indien by die Swart Teologie die antropologiese sosiologiese die inhoud van die teologie bepaal, kan ons dit as Swart "teologie" beskryf. By nadere ontleding van die Swart Teologie blyk laasgenoemde ongelukkig in groot mate die geval te wees (7:9).

Afrikanisasie in die goeie sin van die woord (8:38) oftewel dan "swart" Teologie, is nie iets wat deur die sendende kerk voltrek kan word nie, en ook nie iets wat gou (of ooit?) afgehandel kan word nie. Wat eersgenoemde punt betref moet 'n sendende kerk, indien van ander kulturele agtergrond as die sendingkerk, hoofsaaklik sorg dat die bybelse teologie suiwer oorgedra word en wel op'n wyse dat die jongkerk self die eie gestaltegewing sal realiseer. "Die Afrikaan is ... gevoelig teen 'n afrikanisasie waaroor hy nie beheer het nie en egter nog wat sou neerkom op ' $n$ 'policy of archaization, of insisting on the imitation of some practically disused folk arts' ... Dit is voor die hand liggend dat die uitvoering van die program van afrikanisasie 'n sterk inheemse leierskap veronderstel" (6:21). Wat die tweede punt betref kan ons maar net daarop let dat die gevestigde Europese 
kerke byvoorbeeld nog steeds die evangelie in sy midde moet onthelleniseer. Hierdie proses is 'n kerklike lewensproses waar die "ou" suurdeeg van ondeug altyd uitgesuiwer moet word (1 Kor 5:78).

\section{Herkoms}

"Hoewel daar 'n verband tussen die vroeë ontstaan van die separatiste kerke en die gemeenskaplike verset teen blanke oorheersing is, het die Swart Teologie tog in Amerika ' $\mathrm{n}$ min of meer de novo ontstaan" (6'23). Wat die separatisme betref word gereken dat hierdie verskynsel wat reeds meer as 6000 bewegings of groepe het, 'n Afrika-gestalte wil wees van die Christendom (1:90; 12: Hfst 2). Ander wil die separatisme eenvoudig "afskryf as 'post-christianity' of as 'n brug terug na die heidendom" (7:9). Wat die reaksie op blanke oorheersing betref, het die ander volke die blankes nie meer as onoorwinlike supermense gesien nie. Hierdie wending het gekom nadat Japan Rusland in 1905 gewen het, en is versterk deur die eerste en tweede wêreldoorloë (7:9).

Die agtergronde van Swart Teologie lê dus in die 19de eeu "en wel by die Neger - en Bantoe-separatistekerke ... Daar is dus, sowel in die VSA as in Suid-Afrika ' $n$ bepaalde voedingsbodem vir' $n$ beweging soos die Black Theology omdat die Ethiopiese-tipe separatistekerke daar 'n besliste antipatie teen die Blanke bestaan" (10:15). Die wortels kan egter nog verder terug gevind word. 'n Kongolese meisie, Kimpa Vita, gedoop Béatrice, het "teen omstreeks 1700 'n protesbeweging teen die $\mathrm{R} \mathrm{K}$ Kerk gelei ... Christus (sou) aan haar verskyn (het) as 'n Swartman en al sy dissipels was swart. Hy het Hom geidentifiseer met die onderdrukte inheemse bevolking teen die wit uitbuiters en verdrukkers" (11:47).

In Amerika leun die Swart Teologie swaar op ideologiese onderbou soos die Marxisme en neo-marxisme. Uit die New Left beweging, gevoed deur die gees van Herbert Marcuse, Mao Tse Tung, Fidel Castro en Che Guevara, het die Amerikaanse Black Power-beweging gekom met Black Consciousness as wisselbenaming en die Black Panther-beweging as besondere gestalte. "Black Theology wil, volgens die gesaghebbende prof James $\mathrm{H}$ Cone, niks meer as die religieuse interpretasie van hierdie basies marxistiese of neo-marxistiese Black Power-ideologie wees nie" (10:16). "Prof James H Cone van Union Theological Seminary in die VSA, sien Black Theology, Black consciousness en Panafrikanisme feitlik as wisselbegrippe en in ieder geval as denkpatrone wat uit 'n gemeenskaplike voedingsbodem kom" (10:14). Prof Cone wat die eksponent van die mees militante vorm van die Swart Teologie in Amerika is, word as die geestelike vader daarvan in Suid-Afrika gesien $(6: 24 ; 11$ : 47-48; 10:16). 
Die Swart Teologie het in Suid-Afrika in Maart 1971 (1:93) sy verskyning gemaak toe dit deur 'n Blanke - hoe ironies - Basil Moore, hierheen gebring is. Hy het hiervoor die veelrassige University Christian Movement (UCM) te Roodepoort gebruik. "Onder andere omdat veelrassigheid nie bestaanbaar is met die wese en strewe van die Amerikaanse Cone-iaanse Swart Teologie nie, is die UCM ontbind. In die plek daarvan is die uitsluitend swart South African Student Organisation (SASO) gestel" (6:24). In vele frontorganisasies word die idees verder gedra soos in die Black Theology Movement, Black People's Convention, Special Programme on Christianity in a Apartheid Society (SPROCAS) ensovoorts $(10: 16,24,25)$.

\section{Inhoud}

Inhoudelik lê die herkoms van die Swart Teologie "nie soseer in Amerika of in die tradisie van Afrika nie, maar veel eerder in die moderne Teologie van die Rewolusie wat sedert die vergadering van die Wêreldraad van Kerke te Genéve (1966) soveel opgang maak" (1:95). By noukeurige ontleding en oorweging moet met hierdie standpunt saamgestem word. "We kunnen zeggen dat we het volkomen eens zijn met de uiteenzettingen en bewijsvoeringen van $\mathrm{dr}$ Pont. Deze onderkent beter de revolutionaire en anti-evangelische tendenzen van de Zwarte Theoldogie dan dr Bosch" (13:79).

Volgens Cone leef Swart Teologie op ses bronne. "Hier is die Bybel nie net een van ses bronne vir die teologie nie, maar verskyn eers vyfde op die lys! Hieruit, en uit baie ander opvattings van die Swart Teologie, is dit duidelik dat enige kerk wat ooit Swart Teologie aanvaar, nie langer aanspraak op apostolisiteit kan maak nie. Geen wonder dat die Bybelse eskatologie in die Swart Teologie verlore gegaan het nie" (14:230).

Oor genoemde ses bronne sou veel gesê kon word (15:74-78). Enkele aantekeninge kan hier as riglyn dien:

\section{Swart ervaring}

In die Swart Teologie (S T) is tipies neo-marxisties die vertrekpunt nie God nie, maar die mens. S.T. wil uitdruklik nie 'n teologie in die sin van leer aangaande God, wees nie (10:17). Sy vertrek is ook nie bloot humanisties by die mens of by die mens as skepsel van God nie, maar by ' $n$ bepaalde groep mense in 'n spesifieke konteks, omstandigheid of ervaring (10:18). Waar dit in SA die swartmense is, is die eerste "heilsvraag" hoe groot die lyding van die swartmens in SA is? Wie nie hierdie vraag aan lyf vanweë sy black experience van vernedering en lyding kan beantwoord nie, mis die belangrikste bron van S.T. Omdat S.T. ' $n$ teologie van revolusie en bevryding is, 
en die ware teologie sou wees, moet Christelike teologie Swart Teologie wees of dis geen teologie nie! "Black Theology glo dat God die kant van die swartes gekies het teen die wittes ... 'In order to be Christian theology, white teology must cease being white theology and become Black Theology by denying whiteness as a proper form of human existence and affirming blackness as God's intention for humanity'" (15:75).

\section{Swart geskiedenis}

In Amerika het hierdie bron te doen met die wyse waarop swartes as slawe en as nie-mens na Amerika gebring is. In S A ook word die tweede "heilsvraag" in hierdie verband: Wat was die verlossingseffek van die koms van die blanke kolonis op die godsdiens, kultuur en lewensstyl van die swart man? (10:18).

Die implikasies van die swart geskiedenis vir die openbaring van God, moet volgens Cone in die volgende rigting gesoek word: “... Black Theology refuses to accept a God who is not identified totally with the goals of the black community. If God is not for us and against white people, then he is a murderer, and we had better kill him" (15:76).

\section{Swart kultuur}

In samehang met die Swart Ervaring en die Swart Geskiedenis word die Swart Kultuur as 'n openbaringsmedium van God gesien. Die ontworsteling van die Swart Kultuur uit 'n situasie van onderdrukking word gesien as Goddelike woord, daad en eksistensie (10:19; 15:76). Genoemde sake tot sover is "ongeveer die grootste inhoud van die Black Theology. Die situasie bepaal nie net die koers en rigting van hierdie teologie nie maar ook die inhoud van hierdie teologie" (10:19).

\section{Openbaring}

Terwyl die Swart Ervaring, Geskiedenis en Kultuur openbaringsmedia is, is die Swart Teologie (en daarmee teologie) situasie-teologie. Maar omdat die drie genoemde bronne ook aandui dat deur die eksistensiële situasie van die swartmens geworstel word tot "liberation", is dit ook 'n Teologie van Bevryding Openbaring is dus 'n voltooide gebeure plus 'n voortgaande gebeure plus 'n swart gebeure (15:787). 


\section{Die Skrif}

Soos dit uit die volgende sal blyk word die Skrif nie as die primêre en normerende getuienis van die openbaring van God gesien nie. "Die Heilige Skrif, die oorkonde van die openbaring van God, (word) slegs gebruik vir so ver dit die vasstaande argumente van die ideologie waarop die Black Theology gebou is, verder bewys en verstewig" (10:19).

\section{God}

Die drieënige God van die Bybel word nie aanbid nie en uitdruklik nie aanvaar "as 'n persoon, almagtig, alwetend en as die hoogste gesag in die hemel en op die aarde nie" (10:20). God is en moet swart wees. "The blackness of God then means that the essence of the nature of God is to be found in the concept of liberation" (15:77).

Vanweë hierdie siening van God word God gesien as 'n Bondgenoot God, nie as die Verbondsgod nie; as 'n wordende God, nie as die God wat van ewigheid af tot in ewigheid is nie; as 'n lydende God, nie as die ewig heerlike en heilige skepper Verlosser en Voleinder nie.

As God 'n Bondgenoot God is, sou God net bestaan so ver as sy bongenoot bestaan. Dan is "het zijn van God niet te denken zonder het zijn van de mens" (13:18). So 'n Bondgenoot God is dan ook 'n verborge God buite die Swart teologie. Maar die God van die verbond, van die Bybel, is nie 'n verborge God nie "en wanneer Jesaja spreekt over een God, die zich in het verborgene houdt (Deus absconditus), (Jes 45:15) ... dan is het antwoord aan Jesaja Ik heb niet in het verborgene gesproken, in een donkere plaats der aarde, (Jes 45:19). Zo ook in Jesaja 48:16: Ik heb van den beginne niet in het verborgene gelsproken ... Hij resideert in het verborgene van zijn tent (Ps 97), maar Hij houdt zich niet verborgen door niet te spreken" (13:69). 'n Bondgenoot God is essensieel 'n wordende God.

In die Teologie van die Hoop "(lê) die grond van die hoop vir Moltmann nie in die verlede, in wat gebeur het nie, maar in die toekoms, in wat nog sal gebeur, terwyl datgene wat ook gebeur het naamlik die opstanding van Christus, ook in dieselfde toekoms gegrond is" (16:126). "Ook hy (Jürgen Moltmann) is van mening dat Jesus nie werklik liggaamlik opgestaan het nie. Die verhaal van die opstanding was waarskynlik die resultaat van ' $n$ visioen. Tog meen hy dat die opstanding van Jesus in 'n sekere sin waar is ... ' $n$ simbool van hoop dat daar iets beters is as die huidige" (17:7). In hierdie kader word Jesus nie gesien as die seun van God nie. As seun van die mens, die mens mens, word Hy die Seun van God, God. God is nog 
nie, maar sal wees. Die mens word God. In hierdie kader word "religieuse verbalisme" verwerp en so ook "christian quetism" (18:69). Hier word die promissio Dei $=$ promise of God, verstaan as pro-missio Dei $=$ God se sending vooruit (18:64). Op hierdie wyse word gesê: "Through Christ, God presented a new world to man but this new world must be realised in time" (18:69). "In this process, mission should take an active part and thus realise the Kingdom" (18:70). Op hierdie wyse word die eschaton gerealiseer deurdat "God created hands for himself through men's hands, as well as feet through men's feet, and his mouthpiece though human speech" (18:72).So word God mens en mens God!!

Hiermee kom ons deels by die oeroue gnostiese dwaling van die Ophiete (13:71). "Bloch paralleliseert de Zoon des Mensen in Joh 3 met de paradijsslang ... De Ofieten hebben de consequenties getrokken en de paradijsslang in betrekking op Jesus als de usurpator van Jahve ... Zo is de slang niet een duivel maar een verlosser en bevrijder die de mens helpt in opstand te komen tegen een despotische godheid die hem onmondig wil houden ... En dan komt het motief van de wordende god, van de groeiende, de zich evoluerende god duidelijk naar voren ... Dit motief van de wordende, de groeiende, de evoluerende, de volmaakte, wordende god is in wezen satanisch van oorsprong. Deze gehele idee stoelt op de pseudoopenbaring van de slang in het paradijs, is een vervalsing van de revelatio Dei ... Het motief van de slang als heilandsfiguur is in alle religies terug te vinden ..." $(13: 72,75)$. Waar die openbaring die bron van teologie is, is die pseudo-openbaring die bron van ideologie. In die antichris word die hoogtepunt gevind van die mens wat homself in die plek van God soos God stel (2 Tess 2:4).

Omdat God dan ' $n$ wordende God is, en die lewe uit lyding en onderdrukking bestaan, is God 'n lydende God. "Dat is de herlevende belangstelling voor het theopaschitisme of ook wel het Patripassianisme" (13:76). Siende dat die swartmens die lydende mens is, is die wordende God swart - dus Swart Teologie!

\section{Die mens}

Swart Teologie het ' $n$ ander antropologie as die Bybel. "Byna met wrewel word dan ook die Bybelse leer van die mens as sondaar voor God verwerp omdat hierdie pessimistiese antropologie niks anders sou wees nie as ondermyning van die nie-Blanke se selfrespek en 'n bevestiging van die minderwaardigheidsgevoel waarvan hy ontslae moet raak. Al sonde wat die Black Theology ken, is die sonde van die onderdrukking, die sondige bestaande strukture, die sondigheid van die Blanke" (10:20). 


\section{Verlossing}

Vanuit bogenoemde onbybelse antropologie is die onbybelse verlossingsleer te verstaan. Onder 'n latere punt sal die verlossingsbegrip van die S.T. vollediger behandel word as die eksodus-teologie. Hier kan wel daarop reeds gewys word dat "die vyand wat oorwin moet word, ... die sogenaamde wit rassisme (is)" (15:78). "Change" en "conversion" het feitlik wisselbegrippe geword (10:20).

\section{Jesus Christus}

Dis reeds duidelik dat Christus nie as die Seun van God volgens die Bybel, gesien word nie; nie as Verlosser van sondaars nie; maar as die rebellerende mens en die groot revolusionêre voorbeeld. Om Christus so te sien, moet daar natuurlik spesifieke beskouings oor die Bybel wees, waarby ons sal kom.

\section{Die Kerk}

Omtrent niks van wat ons op grond van die Bybel oor die kerk bely, kom in die S.T. tereg nie. In die S.T. is die tans bestaande kerk eintlik blanke instrumente vir die onderdrukking van swartmense. Swart Teologie moet van die kerk 'n agent maak om die sogenaamde status quo van blanke rassisme en grondbesit omver te werp deurdat "die blanke aan die norme, eise en konvensies van die nie-blanke sal moet konformeer" (10:23).

\section{Die Bybel}

Uit die bostaande is dit reeds duidelik dat die Heilige Skrif nie die reformatoriese plek van sola scriptura in die S.T. inneem nie.

Die Bybel speel hoofsaaklik ' $n$ rol net wanneer dit in die struktuur van die Swart Teologie 'n hulpmiddel is. "Om, dit te kan doen, word die evangelie Markus en die sinoptici baie gou van die toneel verwyder deur hulle af te maak as onbetroubare getuies van die historiese gebeurtenisse en van Jesus self ... Hulle het ... die boodskap en betekenis van Jesus vervals deur Hom as ' $n$ pasifis voor te stel ... Net so word ... Paulus verwerp ... want as Romeinse burger (was hy) deel van die sogenaamde establishment, deel van die onderdrukkende mensontérende sisteem van die Romeine waarteen Jesus die stryd aangeknoop het. Buitendien het Paulus op sy sendingreise hom onttrek uit die gekoloniseerde Palestina en skrywe hy sy boodskap aan mense buite Palestine wat nie betrokke is by die intense vryheidsstryd van die Jode nie ... Met die hulp van Josephus se geskrifte en deur die teorieë wat geponeer is deur prof S G F Bran- 
don word ' $n$ totaal nuwe beeld van Jesus as vryheidsvegter en uhuru-messias geteken (10:21).

Deur hierdie sogenaamde herinterpretasie van die Bybel "in die lig van die eksistensiële situasie waarin die nie-blanke homself bevind" (10:21), word Jesus as eloot of vryheidsvegter gesien. Jesus sou geen immanente versoeningsdaad kom verrig het nie, maar Hy het die boodskap gebring. "God self sal nie die stryd vir die mens stry nie. Die mens moet deur die herontdekking van sy eie-waarde, deur die beklemtoning van sy menslike selfrespek homself verlos uit die ekonomiese, kulturele en politieke slawerny van die bestaande strukture ... Jesus se opstanding leer die mens dat die kwaad, naamlik die bestaande strukture, nie oppermagtig is nie maar oorwin kan word" (10:22).,

Daar word nie net dele van die Bybel geskrap en ander anders geïnterpreteer as wat dit self geïnterpreteer wil wees nie, maar daar word ook ten spyte van die Bybelse waarskuwing selfs direk getrag om die Bybel uit te brei. Ook ons belydenis in die NGB oor die kanonieke boeke is dan daarmee heen. "Swart kerkleiers (het) in Cleveland, Ohio, met 'n beweging begin om nóg 'n boek by die Bybel te gevoeg te kry, te wete, 'The book of Martin Luther King'. Die boek wat hierdie kerkleiers volgens die berig in gedagte het, is Martin Luther King se 'Letter from Birmingham Jail' ... Hierdie beweging spruit uit die derde 'Swart Teologie Projek' wat onder leiding van eerw Muhammed Kenyatta aangepak word ..." (19:197).

Op veral een motief word uit die Bybel swaar klem gelê: Eksodus. Die Joodse wysgeer Ernst Bloch wat by Karl Marx se gedagtes van hoop op ' $n$ beter wêreld in hierdie bedeling aansluit, sluit ook by die Siriese, gnostiese sekte van die Ophiete aan deur met 'n foutiewe eksegese van Johannes 3:14 Jesus met die Paradysslang te vergelyk (16:124). Jesus is die rebellerende, bewegende, eksodus-god. Moltmann en andere, veral in die Teologie van die Hoop, sien die kerk se sending om konkrete diens aan die wêreld te lewer deur met 'n nuwe eksodus die koninkryk van God te realiseer (16:127). Die eksodus-motief verkry dan ook 'n revolusionêre faset soos waar te neem ook by Richard Schaull, Harvey Cox, Dorothee Sölle, J Verkuyl (16:128:9).

Die Swart Teologie 'makes an assault on all Western modes of worship and cries like Moses: 'let my people go' ... (76:27). Maar die eksodus-motief, wat ook vir Israel van so 'n groot belang was dat hulle jaartelling by die uittog uit Egipte begin ( 1 Kon 6:1), word by die S.T. heeltemal uit sy Bybelse konteks uitgelig en in die swart konteks gekontekstualiseer. Omdat die eksodus-motief van die S.T. inpas by die Teologie van die Revolusie, die Hoop ensovoorts waar God wordend gesien word en as die wordende deur die geskiedenis van die lydende mensheid, "word die eksodus-motief uit die open- 
baringgeskiedenis weggeneem en het 'n plek gekry in die profane geskiedenis" (16:144). Heilsgeskiedenis verdwyn eintlik deurdat die profane die heilsgeskiedenis word. "Ons kry hier (by H Berkhof) 'n volkome historiese teologie: Gọd self deurloop 'n geskiedenis" (16:1237). Omdat die eksodus-motief in die S.T. "losgemaak word van God se verbond met Israel en sy bedoeling met hierdie volk vir die heil van die wêreld ..." (20:14). moet ons kortliks noukeuriger na hierdie saak kyk.

"When Cone says that the exodus was for the Old Testament what the resurrection of Jesus was for the New, he is perfectly right" (21:'58). Maar wat reg is moet in regte verband behou word anderts geskied geregtigheid nie. Daarom is die volgende opmerkings van belang;

1 Die uittog uit Egipte, as bevryding vir Israel uit slawerny, geskied nie militer of revolusionêr of eiehandig nie, maar deur 'n wonder van God (231:61). Dis geen selfverlossing of prestasie van Israel nie (13:15). "The combatant was not a liberation front or terrorist commando but YHWH himself" (22:32). Dit is foutief "to attribute the whole event to Moses himself" $(21 ; 66)$.

2 Die uitredding uit Egipte is ' $n$ versoeningsdaad deur God wat alleen maar geskied nadat God se volk tot hom roep om vergewing van skuld $(21: 61 ; 16: 131)$. Daarom die bloed van die lam (Eks 12:13).

3 Die gemeenskap wat die uittog uit Egipte meemaak "was no political entity but primarily a religious community" (21:61). Die eksodus resulteer in die konstituering van die volk van Jahwe (16:131).

4 Israel se eksodus was 'n uittog, nie 'n revolusionêre of evolusionêre inname of oorname van die landspolitiek nie. "The model of revolution most currently called 'liberation' in our time is for subject peoples (or more accurately for as minority group acting in their name) to seize sovereignty within the land within which they are oppressed ..." (22:32).

5 Alhoewel Israel se uittog kulmineer in die verbondsluiting van God by Sinaï, sodat hulle nou die verbondsvolks is, is hulle egter reeds geroepe volk van God vóór die uittog. "'The people of God" is not everybody ... There is no possibility of constructing a new people on the other side of the Sea if peoplehood does not exist in Goshen ... is prior to Exodus ..." $(22: 35,36,33)$.

6 Eksodus was nie net 'n uittog en dan huru nie, maar ook deurtog en intog (13:69). "Exodus leads not to the promised land but to the desert, and in that desert Sinai is the place of a new enslavement motivated partly by loyalty to the values of Egypt ... Liberation is 
from bondage and for convenant, and what for matters more than what from. If Exodus was the prerequisite of Sinai, in terms of movement, I said, Sinai was the prerequisite of Exodus in terms of motive. It was the reason given to the Egyptians (Ex 8:2, 20, $26 \mathrm{f}$ etc). Even before the arrival at Sinai, the column of fiery cloud was a symbol of Sinai leading them" (22:36).

7 Die Eksodus-motief in sy eie Bybelse verband gesien, lei tot ballingskap vir Israel indien hulle die eksodus polities en nie geloofsmatig sien nie. Nasionale soewereiniteit is nie voorwaarde vir die ware eksodus nie. "Ezra and Nehemiah re-establish the community precisely without national sovereingty" (22:38). Die eksodus tot politieke selfstandigheid in die geval van die uittog uit Egipte, is eintlik 'n uitsondering in die Bybel. "It is the way of Diaspora. This is the model taken over by the New Testament Chruch ..." (22:38). In die eksodiese het Israel weg beweeg van God. In die eksiliese het Israel terug gekeer tot God. "There is only one Exodus in the history of Israel, but on the other hand there are several samples of the way a moral minority can seek the welfare of the city. This advice of Jeremiah (29:1,5-9) was given in the age of the exile agter the defeat of Josiah: but we have the same stance taken by Joseph in Egypt, by Daniel under Nebuchadnezzar, and by Mordecai in Persia and even in a sense by Jonah in Nineveh" (22:38).

Omdat die eksodus uit Egipte nie sy ware vervulling in Palestina kry nie, maar die uiteindelike intog op die nuwe aarde sal wees, het elke eksodus-motief en eksiliese-motief 'n eskatologiese dimensie. Die nuwe eksodus bring weer eens verlossing op die basis van versoening (Jes 40:3-43:28). Dit sal bevryding uit die slawerny van die sonde bring en verlossing uit die mag van die dood (Jes 26:19; Eseg 37:1-14). "Aangesien dit in die nuwe, eskatologiese eksodus sal gaan om die verlossing uit die magte van die sonde en die dood, is die nuwe uittog gekonsentreer rondom die persoon van die lydende Kneg van Jahwe (Jes 53). Die nuwe exodus verskil hierin van die eerste eksodus dat die volk nie meer direk betrokke sal wees by die uittog wat kom nie, soos dit die geval was by die eksodus uit die verlede. Die volk wat verlos sal wees, is inbegrepe in die Verlosser ... Ook sal die nuwe eksodus wat kom, nie net tot die volk Israel beperk bly nie, maar dit sal 'n uittog wees vir alle volke (Jes 45:2224; Sag 9:7) ... Die Ou Testament spreek nie alleen van die oorblyfsel van Israel nie maar ook van die res van die heidene (Jes 45:20; Jer 46-49; Sag 14:16). Die Nuwe Testament sluit in sy spreke oor 'n nuwe eksodus baie nóu aan by die Ou Testament Die evangelis Matteus beskryf die eksodus van Jesus uit Egipte en dan dui hy Jesus aan met dieselfde naam waarmee in die Ou Testament die volk Israel genoem word: my Seun (Matt 2:15; Hos 11:1)... Lukas dui in sy evangelie- 
verhaal die lyding, sterwe en opstanding van Christus aan as 'n eksodus wat Jesus moet volbring te Jerusalem (Luk 9:31) ... By Paulus vind ons die gedagte dat die 'tipiese' woestyngemeente uit die Ou Testament gerealiseer is in die Kerk van die Nuwe Testament ... $\mathrm{Na}$ analogie van die volk Israel wat gedoop is in Moses in die wolk en in die see, is die Kerk in Christus inbegrepe (1 Kor 10:2) ... Ook in die laaste Bybelboek gaan dit nog altyd oor die eksodus van die Kerk al is dit ook 'n eksodus wat 'volksgewys gestruktureer' is. Die volk van God wat in die nuwe eksodus verlos word, bestaan uit die verlostes van verskillende volke ... Die nuwe eksodus het ongetwyfeld ook'n kosmiese aspek. Die ganse skepping sal deel in die verlossing wat kom (Jes 65: 18-25), maar dit mag ons nie tot die gedagte bring dat daar 'n verlossing vir die wêreld buitekant die Kerk is nie. Wanneer die kerk-gedagte losgemaak word van die eksodus-motief dan het ons die eksodus-motief beroof van sy Bybelse inhoud" (16:132134).

So moet ons waak dat ons nie die Bybelse woord en taal van bevryding besig, sonder die Bybelse betekenis nie - "more for window dressing than for content" $(21: 38,40)$. Op die horisontale vlak en in die huidige omstandighede, of dit armoede is of rykdom, is ons eksodus nie te vind nie. Soos die brief aan Diognetus in die tweede eeu ook lui (22:40): "They reside in their respective countries, but only as aliens. They take part in everything as citizens and put up with everything as foreigners. Every foreign land is their home, and every home a foreign land ..." Die Bybel spreek dikwels teen armoede (byvoorbeeld veroorsaak deur slegtigheid, luiheid, onverantwoordelikheid) en ten gunste van armoede (vanweë omstandigheid en afhanklikheidsgevoel ensovoorts). Baie keer spreek die Bybel teen rykdom (as dit byvoorbeeld tot onderdrukking van andere lei, 'n antigoddelike onafhanklikheid gesindheid veroorsaak, ensovoorts), maar ook baie keer ten gunste (wanneer dit as vrug op vlyt, seën op arbeid ensovoorts gesien word). Ons moet waak dat ons eie omstandighede, wat dit ookal mag wees, ons nie van Bybelse balans afgooi nie. Ons moenie só kontekstualiseer dat ons net die "kon" van die omstandighede behou en die "teks" van die Bybel verloor nie. 'n Gebalanseerde studie sou byvoorbeeld in die Bybel aantoon dat rykdom selfs ewigheidsrisiko's het (Matt 19:24). Maar ook dat Salomo, Job, Maria en andere God welbehaaglik ryk was. Die aarde behoort aan die Here en die volheid daarvan (Ps 24). Alles behoort aan die Christene (1 Kor 3:21-23). Jesus was by ' $n$ ryke in sy dood (Jes 53:p; Matt 27:17).

\section{Tradisie}

By hierdie sesde bron van Swart Teologie speel die tradisionele reli- 
gieusiteit van Afrika 'n groot rol. Hier moet ons fyn onderskei tussen twee dinge: openbaringsbron en kommunikasiemiddel.

\section{Openbaringsbron}

Die tradisionele religieusiteit ontvang boodskappe van God op verskillende maniere: "It might come in forms such as dreams and what is called 'malopo' thus the actual posession of the spirit which causes you shake and utter forms of words (23:5) ... In the case of the nation, one of royal family is often a messenger of the family. The nation often respected what he said. This respect could be clearly seen by the suicide of the Amaxhosas (23:6) ... The ancestors are mediators between Modimo and the people ... When christianity came to Africa they truly saw that the ancestors stand in the place of Christ and therefore should be ruined so that Christ could have a place. That's why, from these people who deny christianity because of political, social and economic fulfillments, there is a cry 'back to ancestor worship' then to 'Christ worship'" (23:7).

Daar word opreg geglo dat bovermelde religieuse openbaringe nie psigologies verklaar kan word nie omdat dit "the real Spirit from God" is (23:5). 'n Mens vra jouself egter as Skrifgelowige die vraag hoe dit die Gees van God kan wees as dit byna ' $n$ hele nasie laat selfmoord pleeg? Is dit dan nie ' $n$ bose gees nie? As ' $n$ gees of iemand of ' $n$ engel uit die hemel ons ' $n$ tyding bring wat in stryd is met die geopenbaarde Woord van God, moet ons hom ' $n$ vervloeking laat wees (Gal 1:8,9). Daarom ook moet die geeste op die proef gestel word (1 Joh 4:1).

\section{Kommunikasiemiddel}

Bron en middel moet nie met mekaar geïndentifiseer word nie. Die Woord van God, die Skrifgetuienis, as die enigste bron van die Christelike geloof, word deur middel van elke mens of volk of kultuur ervaar. Dis imperialisties- kolonialisties om een bepaalde godsdiensvorm na ander volkere oor te dra, asof dit die inhoud van die geloof is. Tradisionele rituele hoef nie altyd in alle opsigte summier verwerp en vervang te word met westerse "rituele" nie. Die tradisionele rituele kan op voorwaarde dat die Skrifbron die normerende is, gekersten word en as godsdienstige en liturgiese gestaltes gebruik word. Die rituele dans moet dan definitief nie 'n kommunikasiebron meer wees nie, maar 'n kommunikasiemiddel om die drieënige God te dien en te aanbid.

\section{4 'n Variasie?}

Daar word gemeen dat Swart Teologie maar net 'n variasie op Wit 
Teologie is; en dat Swart Teologie in Suid-Afrika 'n heeltemal verskillende variasie van Swart Teologie in die res van die wêreld is. Is dit so?

\section{Wit Teologie?}

In die 19de eeu veral het die Voortrekkers graag hulle posisie vergelyk met die posisie van Israel wat uit Egipte uittrek na hulle eie land (24:343). Hierdie vergelyking was nooit ' $n$ identifisering van situasies in die sin dat dit uitgegroei het tot ' $n$ Wit Teologie wat vergelyk of gekontrasteer kan word met die 20ste eeuse Swart Teologie nie. Polities is die verskil dat in die 19de eeu die imperiale owerheid nasionale bestaan bedreig en vernietig het, terwyl in die 20ste eeu die nasionale volksbestaan van elke volk juis gesoek en bevorder word. Verder dat in die 19 de eeu daar vreedsaam weggetrek is, 'n parallel met Israel, terwyl in die 20ste eeu daar revolusionêr opstand nagestreef word. Teologies het in die 19de eeu nie rondom die eksodus-motief 'n teologiese sisteem gegroei nie. Die Eksodus het nie as ' $n$ teologiese motief nie, maar as ' $n$ historiese parallel gefunksioneer. Daarom byvoorbeeld het die Voortrekkers nie die "Kanaäniete" uitgeroei, soos in die Bybelse geval die opdrag was - en soos die Amerikaanse vaders dit inderdaad gedoen het nie. Die Voortrekkers het ook nie vermeng met die vreemde mense soos die Roomse en imperiale sending dit toegelaat het nie. Die Voortrekkers het die reg van nasionale bestaan vir hulleself opgeëis en vir alle ander gegun; aan wie ook sending gedoen is.

\section{2 'n Ander Swart teologie?}

Selfs deur Swart Teologie-beoefenaars in Suid-Afrika, word inderdaad toegegee dat "Cone by 'n nuwe ideologie uitgekom (het) wat miskien as 'Blackism' beskryf kan word" (15:78). Maar dan word bygevoeg dat Swart Teologie in Suid-Afrika anders is: "Although some black theologians, especially in North America, have made 'blackness' into some kind of basic criterion for Christian faith and action, this is certainly not true of black theology in South Africa. Allan Boesak has made this quite clear in his criticism of James Cone. For Boesak, as for most others, 'black' has to do with the existential situation, not with the criterion of theology ... Black theologians in South Africa, for example, unlike some Latin Americans, have never advocated any ideological alliance with Marxism. Thus, it is difficult to generalize. Black theology in South Africa is not identical with Latin American liberation theology" (84:159).

Vir die Skrifteoloog is bogenoemde klanke weldadig. In hierdie Suid-Afrikaanse Swart Teologie is daar dus plek vir alle mense - ook 
vir die blankes. Maar laasgenoemde moet dan gereoriënteer word: "It is now time for the black man to evangelize and humanize the white man" (2:162).

By nadere ondersoek blyk egter dat die Swart Teologie hier en oorkant, baie in gemeen het

- By beide is daar ' $n$ integrale eenheid tussen Swart Bewussyn, Swart Mag, Swart Teologie (10, 84:153). Deur die verband tussen "indigenization and contextualization in black theology" word die konsep "communalism" duidelik. "Black theology likewise sees the importance of the kinship system (which played an important role in the emergence of the African independant churches) and relates it to the biblical concept of 'corporate personality'. 'What we discover in the concept as it manifests itself in Israel and Africa is the unique idea of solidarity, a social consciousness that rejects and transcends individualism ...' Under the growing impact of colonization, urbanization, and racial discrimination, African communalism and solidarity have suffered severely in South-Africa ... This is very important for understanding black theology, for black solidarity is of its essence. It rejects any attempts to divide the black community along ethnic or denominational lines, and hence rejects separate development" (84:157). "Hiermee is die Swart Teologie dus in ooreenstemming met stemme wat reeds opgaan om een kerk byvoorbeeld in Malawi, Zair, ensovoorts." (6:30). Dit skyn of swart solidariteit in hoofsake ' $n$ sterker komponent is as etniese kulturele eienskappe $(2: 50,51)$.

- Swart Bewussyn, bevryding en die rol van geskiedenis, speel 'n ewe groot rol in beide S T. "Because, for me (Desmond Tutu), it is a crucial matter that Black consciousness as a theological and evangelical factor because I believe fervently that no reconciliation is possible in South Africa, except reconcilliation between real persons ...' Black Theology is a theology of liberation both in its basic methodology and its content. Theology as (Manas) Buthelezi and others understand it, cannot be separated from what God is presently doing in history, and therefore from the task of the church in the world today" (2:160). "With James Cone we define Black Theology as a theology of liberation that emancipates black people from white racism, and thus provides an authentic freedom for both black people and whites" (25). "We want harmony between black and white. But who is to play the piano in future? For a long time the white man has been on the piano stool. It is time he get off and let the black man play the tune. Obviously the one to bell the cat is similar to the one going off the piano stool,. From this idea reconcilliation (to come to one understanding of the Scripture of both Powers nl. Black and White powers) can be possible if only the different parties comes to 
one and agree that who is to give who what which is a stumbling block on the path of liberty. Liberty which is the mother of reconcilliation" (26:31). Weinig Skriftuurlik skemer deur wanneer die een sonde (white piano player) met die ander (black piano player) vervang moet word! Ewe so ook wanneer politieke vryheid as die moeder van versoening gesien word! As ons uitsprake hierbo vergelyk met die bronne van Swart Teologie, dan is daar merkwaardige ooreenkoms ten opsigte van byvoorbeeld Swart Geskiedenis, Swart Bewussyn, en die kerk se taak.

So ook wat die Skrifgebruik betref deur die Swart Teologie in Suid-Afrika, is daar ooreenkoms met die Swart Teologie oorkant. "It (Swart Teologie in Suid-Afrika) is a theology of protest against apartheid, but it is also one of liberating reconstruction. In the first place, the gospel provides the black theologian with the tools for critique ... The future of the Christian faith in this country will largely depend on how the Gospel proves itself relevant to the existential problems of the Black man' (said Manas Buthelezi)" (2:161). Boesak sê: "Black Theology is (for many black Christians) not only 'part of' the gospel, or 'consistent with' the gospel, it is the gospel of Jesus Christ" (2:165). Hierdie Skrifhantering is 'n oneer vir Skrifteologie.

$\mathrm{Na}$ deeglike vergelyking kom Boshoff tot die konklusie: "Vir Moore (in Suid-Afrika) is Swart Teologie dus net soos vir, Cone ... die fondament van die Swartmag ... Om dit alles saam te vat, die Swart Teologie is nie bereid om die leer oor God, die mens, Christus, die kerk, die Heilige Gees - die spektrum van die Christelike teologie - te bespreek sonder om in elke leerstuk ' $n$ analise van die emansipasie van die swartes te maak nie" $(7: 16,17)$. "Hier is weinig teologie in hierdie nuwe poging ... In soverre daar 'eksegese' is, is die invloed van Cone en sy 'sleutel' sigbaar ... Ten spyte van heftige ontkenning, is die Swart Teologie rassisties. Die repristenasie van die voor-christelike kultuur vind ons by Hitler ook, ... geinspireer deur Wagner se operas met die Germaanse mitologie as tema. Al verskil is: vir die Nazis was Jesus 'n Ariër, dus wit, vir Cone is $\mathrm{Hy}$ swart" (11:51). Nadat ook Meiring sowel die ooreenkomste as die verskille tussen die twee Swart Teologieë nagegaan het, besluit hy: "Swart Teologie kan die einde van die Christendom in Afrika beteken!" (1:95).

\section{Konklusie}

Ten spyte van verskille en aksente wat onderdele raak, het Swart Teologie in hoofsaak ' $n$ afwykende versoeningsleer ten grondslag. In hierdie versoeningsleer (soos by Wiersinga) "is de verzoening van de schuld door de plaatsvervangende voldoening van Christus in $Z i j n$ lijden en sterven vervangen door een verzoening, die zich volt- 
rekt in een God-menselijk gebeuren in de geschiedenis. Daarin vervult Christus de rol van de (unieke) eersteling, in wie dit verzoeningsgebeuren gestalte heeft gekregen en op gang is gebracht. Maar het verzoeningsgebeuren als zodanig zet zich voort in de (lijdens) geschiedenis der menscheid, waarbij lijden en onderdrukking als de oorzaak ervan dicht bij elkaar komen te liggen en de verlossing vooral gezien wordt als (politieke, maatschappelijke, algemeen menselijke) bevrijding ... Ook de z g Black Theology is een vorm ervan, toegespitst op het lijden van de zwarten onder het blanke rascisme ..." $(27: 92,93)$. Swart Teologie is "theologia in loco (J Verkuyl) ... met haar spreken over de zwarte Jezus, met de ontkenning van de vaderschap van God, omdat dit te autoritair zou zijn, en met een racistische verlossingsleer en marxistische heilsideologie ..." (27:128).

Omdat die kommunisme volkere as kultuureenhede wil uitrafel tot 'n dikatoriaal geregeerde wêreldmassa, word die onderskeiding van kulture en ideologie nie gehandhaaf nie, maar kultuur/volk en ideologie word geïdentifiseer (2:viii-xii, 167). Of die Swart Teoloë dit besef of ontken, maar in die struktuur van die Swart Teologie vorm Marxisme die grondslag (27:128). Die Marxisme het akkommodasie hiervoor omdat dit inderdaad vele gesigte het (28:16-35). Die naMarxe ontwikkelingslyne is in hoofsake vierdelig:

1 Die Kommunistiese Marxisme van Rusland en Sjina waar Stalin en Mao die hooffigure was, word ook Nasionaal-Sosialisme genoem

2 Die Ortodokse Marxisme of Trotskyisme word ook InternasionaalSosialisme genoem

3 Die Filosofiese Neo-Marxisme, wat die Duitse Jood (soos Marx) Marcuse tot die New Left-beweging laat uitgroei het, is hoofsaaklik studente aktivisme, geweld en anarchisme, gefundeer in die kritiek teen alle formele instellings. Daarom dat in hierdie kader seksuele vryheid buite die huwelik, homoseksualiteit en aborsie deel van die nuwe moraliteit is. Die neo-Marxisme, teenoor die Marxisme (nrs 1 en 2), is teen 'n geslote politieke sisteem, ook teen 'n nuwe establishment. Hulle wil oop wees en nuwe perspektiese op die Marxistiese basis inent.

4 Die Teologiese Neo-Marxisme is 'n versameling van genitiefsteologieë soos die Teologie van die Hoop, van die Revolusie, van die Strukture, van die Dialoog, van die Swart Bewussyn. "Die Swartmag-teologie is die swart weergawe van die Neo-Marxisme" (28:31).

"Die een saak wat grondliggend is aan alle Marxisme-variante is die horisontalistiese geloof in die maakbaarheid van 'n toekoms deur middel van die afbraak van die bestaande en die selfopbou van 'n menswaardige utopie" (28:19). 
Daar waar teologie, soms onder die vaandel van kontekstualisering, van buite af ' $n$ doel gegee moet word, word die doel gemaklik 'n ideologie. 'n Moderne ideologie verskil miskien wat omvang en kompleksiteit betref van die paradyslike sondeval, maar nie in essensie nie. Die sataniese motief bly humanistiese selfvergoddeliking.

\section{Verwysings}

1. P G J Meiring, Die Agtergrond van Swart Teologie in Afrika en Suid-Afrika, NGTT, Maart 1976.

2. John W de Gruchy, The Church Struggle in South-Africa, Foreward by Alan Paton, Rustica Press, Cape Town, 1979.

3. Byang $\mathrm{H}$ Kato, Theological Pitfalls in Africa, Evangel Publishing House, P O Box 1015, Kisumu, Kenya, 1975.

4. DC S van der Merwe, Sending en Uitverkiesing.

5. H G van der Westhuizen, Sendingbeleid, Lesing Universiteit van die Noorde.

6. I J van der Walt, Aspekte van die Afrikanisasie van die Kerk gedurende die Twintigste Eeu, IBC-Studiestuk nr 90, April 1975.

7. CW H Boshoff, Die Swart Teologie as Bevrydingsbeweging, NGTT, Januarie 1973.

9. P E S Smith, Swart Teoldogie en die Sending van die Kerk, NGTT, Januarie 1973.

10. A D Pont, Black Theology - Voorbereiding vir die Revolusie? In die Skriflig, Maart 1973.

11. L F Schulze, Die Swart Teologie, In die Skriflig, Sept 1975.

12. G C Oosthuizen, Post-Christianity in Africa, 1968.

13. D K Wielenga J D zn, Over de Betekenis van de Wet des Heren in de Zendingsprediking (1), Kampen 1974.

14. Andries Odendaal, Die Apostolisiteit van die Kerk, NGTT, Junie 1975.

15. J J Steenkamp, Die Hantering van die Rassevraagstuk in die Ekumeniese Beweging, B D III, Universiteit van Pretoria.

16. L Floor, T T Spoelstra e a, Die Saailand is die Wêreld, Jubileum-uitgawe, Hammanskraalse Teologiese Skool.

17. J L P Wolmarans, Het Jesus werklik opgestaan? Die Hervormer, Nov 1979.

18. Nico J Smith, A Missiology of Hope, Missionalia, Aug 1974.

19. Redaksie, Nog'n Bybelboek? Die Kerkbode, 15 Aug 1979.

20. J A Heyns, Teologie van die Revolusie, IBC-Studiestuk 128, Julie 1978.

21. Ferdinand Deist, The Exodus Motif in the Old Testament and the Theology of Liberation, Missionalia, August 1977.

22. John $\mathrm{H}$ Yoder, Exodus and Exile: The Two Faces of Liberation, Missionalia, April 1974.

23. J M Mamobolo, The Place of Preaching in Southern Africa, Task for Practical Theology, Universiteit van die Noorde, Sept 1979.

24. H L Pretorius, Wit/Swart bevrydingsteologie in Suid-Afrika, NGTT, Septy 1977.

25. P Mosoeu, Black Theology, Task for Dogmatics, University of the North, 1979.

26. Cecil Northcott, Christianity in Africa, SCM-Press, London, 1963.

27. J P Versteeg e a, Gij de Eertijds verre waart ... Een Inleiding tot de Gereformeerde Zendingswetenschap, De Banier-Utrecht, 1978.

28. M C Boshoff, Die Gesigte van die Neo-Marxisme, In die Skriflig, Sept 1979. 